\title{
Comparison of the Effect of Supraperiosteal Versus Subperiosteal Dissection on the Growing Rabbit Maxilla
}

\author{
Nicola Mannucci, M.D. \\ Ornella D'Orto, M.D. \\ FEDERICO BIGLIOLI, M.D. \\ Roberto Brusati, M.D.
}

\begin{abstract}
Objective: To achieve closure of wide unilateral cleft lip repair without tension of the cleft lip margins, a large undermining, especially of the anterolateral surface of the maxilla, is needed. Two types of dissection are feasible: supraperiosteal or subperiosteal. The aim of this study was to investigate whether there are differences in maxillary growth between healthy rabbits after supraperiosteal or subperiosteal dissection.

Methods: Twenty-four male 7-week-old New Zealand white rabbits were divided randomly into three groups: eight control animals (untreated); eight animals undergoing supraperiosteal dissection of the left surface of the maxilla, and eight animals undergoing subperiosteal dissection of the left surface of the maxilla. All of the treated animals were operated on by the same surgeon at age of 7 weeks and sacrificed at 27 weeks together with control group animals. Seven cephalometric measures (representing aspects of maxillary length, width, and height), on the left side, were taken on the cleaned skull of the rabbits, and the results were analyzed statistically.

Results: No significant differences in maxillary growth were noted across the three study groups.

Conclusions: The supraperiosteal or subperiosteal undermining of the anterolateral surface of the maxilla does not seem to interfere with the growth of the normal maxilla in the rabbit.
\end{abstract}

KEY WORDS: cleft lip, maxillary growth

Hypoplasia of the maxilla is one of the most frequent deformations in treated patients with a cleft lip and palate. Some authors believe that the hypoplasia might be caused by palate repair (Graber, 1949; Herfert, 1958; Schweckendiek, 1973), others to lip repair (Bardach and Eisbach, 1977; Eisbach et al., 1978; Bardach et al., 1982; Bardach and Mooney, 1984; Bardach and Kelly, 1988, 1994; Normando et al., 1992; Kapuku et al., 1996).

In cleft lip surgery, supraperiosteal or subperiosteal maxillary soft tissue undermining is a consolidated and widely used procedure to facilitate lip repair with reduced tension. The method usually adopted by our Cleft Palate Centre is wide subperiosteal undermining of the anterolateral surface of the maxilla on the cleft side, as suggested by Delaire (1975) and others (Trott and Mohan, 1993). There are published state-

Dr. Mannucci is Head of the Department of Maxillofacial Surgery, S. Maria degli Angeli Hospital, Pordenone, Italy. Dr. D’Orto is a Resident, Department of Maxillofacial Surgery, San Paolo University Hospital, Milan, Italy. Dr. Biglioli is Assistant Professor. Dr. Brusati is Head of the Department of Maxillofacial Surgery, San Paolo University Hospital, Milan, Italy.

Submitted November 2000; Accepted February 2001.

Reprint requests: Dr. Ornella D'Orto, Department of Maxillofacial Surgery, San Paolo University Hospital, Via A. di Rudini 8, 20142 Milan, Italy. E-mail Roberto.Brusati@unimi.it. ments that supraperiosteal dissection is preferred to the subperiosteal because it has a less disturbing effect on maxillary growth (Millard, 1976; Bardach and Salyer, 1987), but we could not find any experimental research comparing these two procedures. In fact, Bardach (Bardach et al., 1982; Bardach and Mooney, 1984; Bardach and Kelly, 1988, 1994) described the negative effects in rabbits of supraperiosteal dissection in surgically induced clefts, although Munro (1978) reported no craniofacial growth impairment in normal pigs after wide facial subperiosteal dissection. The aim of this study was to com-

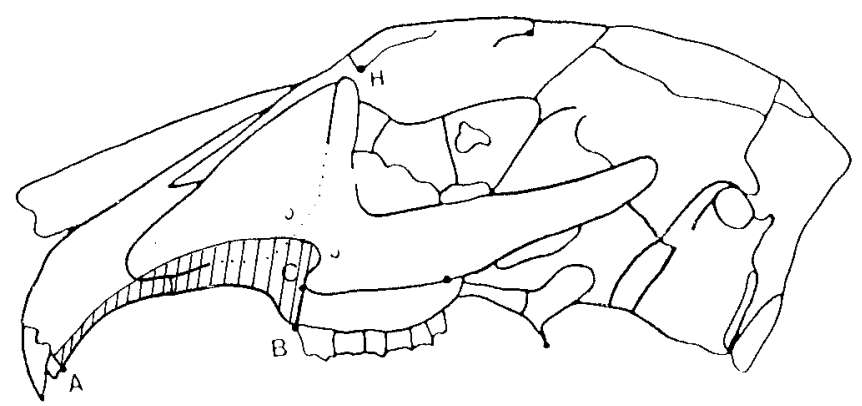

FIGURE 1 Drawing of the dissection of the anterolateral surface of the rabbit maxilla. 


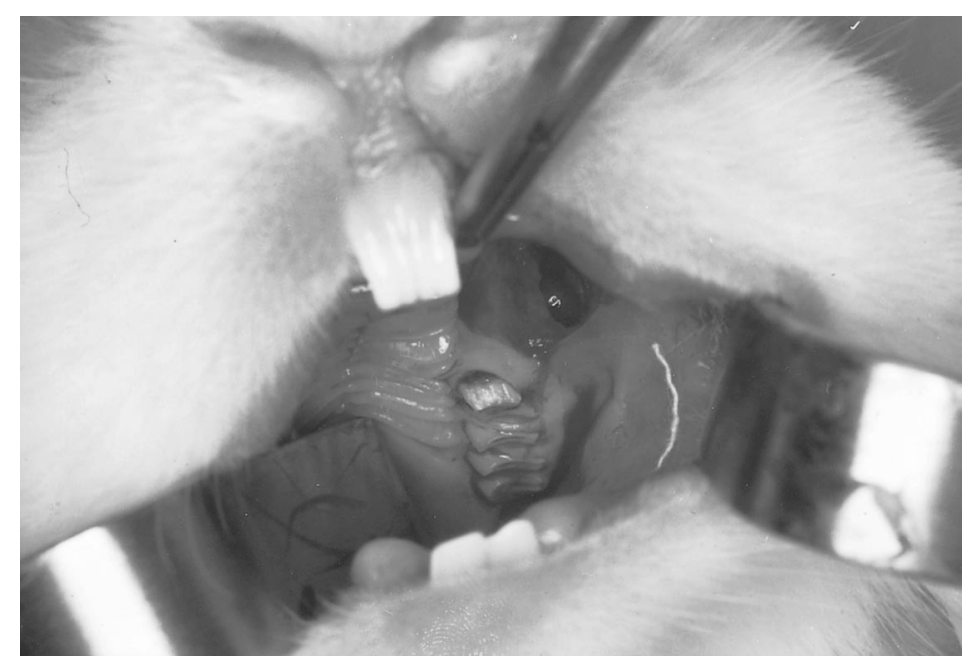

FIGURE 2 Intraoperative view of the subperiosteal dissection.

pare the effects of both undermining methods on the normal growing rabbit normal maxilla.

\section{MATERIALS AND METHODS}

Twenty-four male New Zealand white rabbits were used in this study. They were randomly assigned to one of the following three groups: group 1 was unoperated control (8 rabbits); group 2 was animals undergoing subperiosteal undermining of the left surface of the hemimaxilla (8 rabbits); and group 3 was animals undergoing supraperiosteal undermining of the left surface of the hemimaxilla (8 rabbits).

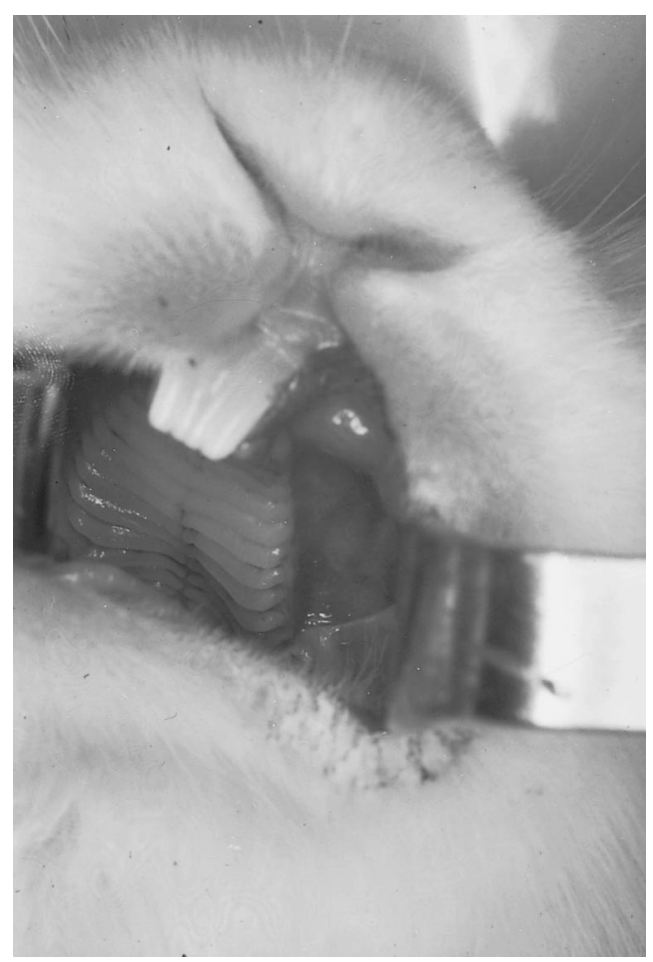

FIGURE 3 Intraoperative view of the supraperiosteal dissection.
The surgical procedure was conducted at 7 weeks of age under total anesthesia using $1.7 \mathrm{cc}$ Inoketam (ketamina chlorhydrate) and $0.8 \mathrm{cc}$ Rompun (intramuscular injectable $2 \%$ solution). Intramuscular antibiotics $(0.5 \mathrm{~mL}$ Baitril (enrofloxacine), injectable $2 \%$ solution) were administered during the operation. The same surgeon performed all surgical procedures. All procedures were performed on the left side maxilla (Fig. 1).

Analyses of preoperative weight and maxillary length and width showed that the groups were homogeneous in terms of facial structure and physical size.

\section{Surgical Techniques}

The left alveolar crest was first incised from the central incisor to the anterior alveolar margin of the first homo-lateral molar (Figs. 2 and 3). A subperiosteal (group 2) or supraperiosteal dissection (group 3) was then carried out on the anterolateral side of the left maxilla, up to the point of emergence of the infraorbital nerve. Finally, a mucous or mucoperiosteal flap was closed. No complications were noted in the postoperative period. All of the animals recovered to normal function a few minutes after awaking from the anesthesia and had no difficulty taking nourishment.

All animals were sacrificed at 20 weeks postoperatively (27 weeks old), an age that ensured complete facial growth (Engdahl, 1972). One animal (in group 3) died 17 weeks after the operation, the result of cardiocirculatory collapse. However, this animal was included in the analysis. On the cleaned and bleached skull of each animal of all groups, seven cephalometric measurements were made on the left (treated) side similar to those used by Bardach et al. (1982) and Bardach and Kelly $(1988,1994)$, using a precision gauge. Three dimensions were considered (Fig. 4): maxillary width (LJ, N-NS), maxillary length $(\mathrm{AB}, \mathrm{AC}, \mathrm{AE})$, and maxillary height $(\mathrm{HC}, \mathrm{BH})$. 

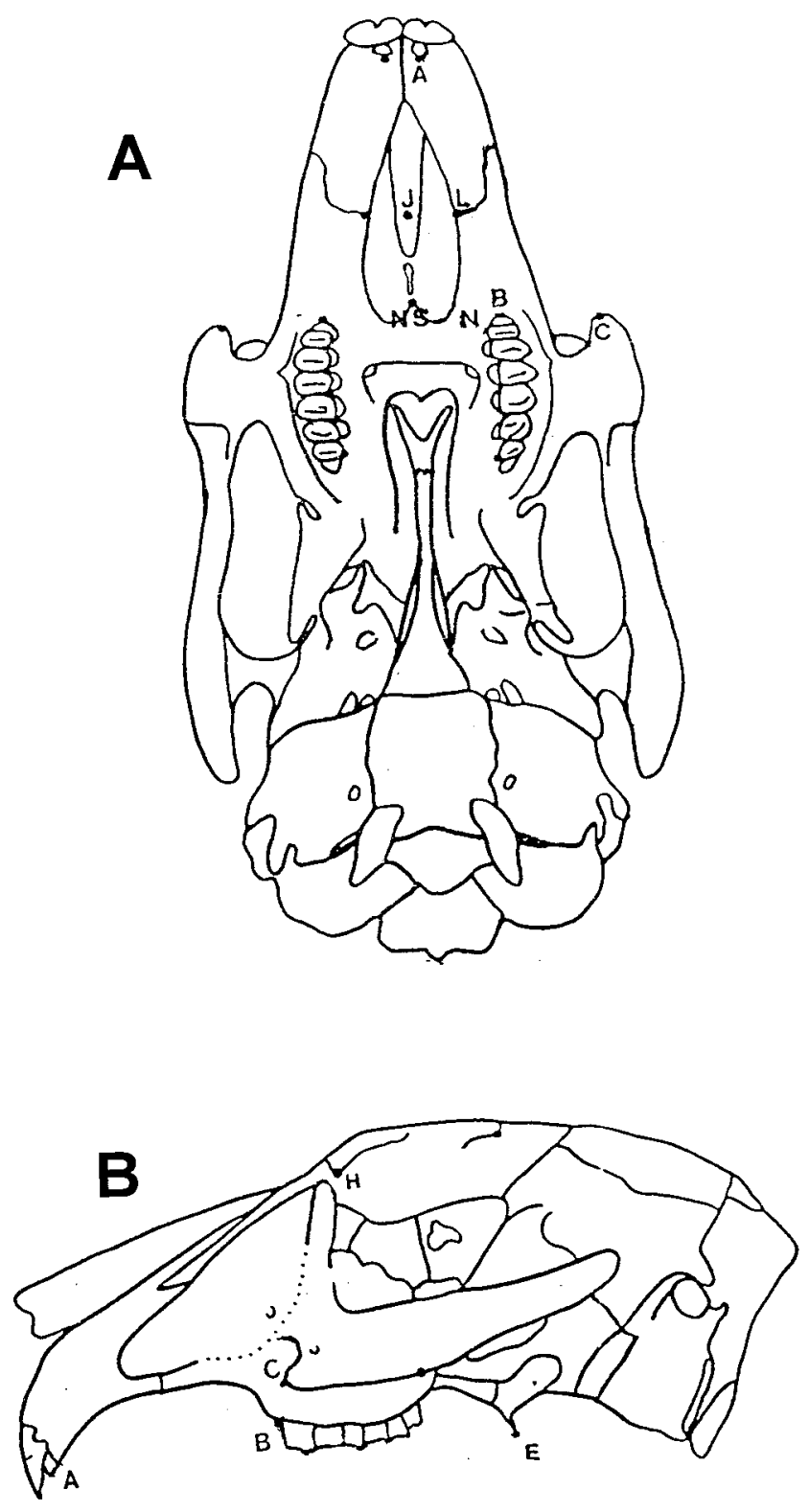

FIGURE 4 Cephalometric measures. A. Maxillary width: LJ (from the medial margin of the premaxillary-maxillary suture on the cleft side to the midline of the nasal septum); N-NS (between the medial margins of the first molar and posterior nasal spine). Maxillary length: AB (from the posterior margin of the alveolus of the posterior incisor to the anterior margin of the alveolus of the first molar); AC (from the posterior margin of the alveolus of the posterior incisor to the masseteric spine of the $\mathrm{zy}$ gomatic process); $\mathrm{AE}$ (from the posterior margin of the alveolus of the posterior incisor to the pterygoid hamulus). B. Maxillary height: HC (from the anterior supraorbital process of the frontal bone to the masseteric spine of the zygomatic process); $\mathrm{BH}$ (from the anterior supraorbital process of the frontal bone to the anterior margin of the alveolus of the first molar (from Bardach et al., 1982).

\section{Statistical Analysis}

Group differences across the measured parameters were statistically analyzed using the analysis of variance function in STATA 6.0. A $p$ value $<.05$ was considered significant.
TABLE 1 Mean (mm) and SD for Each Measurement

\begin{tabular}{|c|c|c|c|c|c|}
\hline Variable & n.sub. & Mean $(\mathrm{mm})$ & $S D$ & Min & $\operatorname{Max}$ \\
\hline \multicolumn{6}{|c|}{ Group 1 (control) } \\
\hline $\mathrm{LJ}$ & 8 & 2.6125 & .294897 & 2.4 & 3.3 \\
\hline $\mathrm{N}-\mathrm{NS}$ & 8 & 8.0 & .6928203 & 7.0 & 8.8 \\
\hline $\mathrm{AB}$ & 8 & 30.425 & 1.114514 & 28.5 & 32.5 \\
\hline $\mathrm{AC}$ & 8 & 35.875 & 1.16343 & 34.0 & 37.9 \\
\hline $\mathrm{AE}$ & 8 & 59.325 & 2.476027 & 55.9 & 63.8 \\
\hline $\mathrm{HC}$ & 8 & 32.325 & 1.782253 & 29.5 & 34.8 \\
\hline $\mathrm{BH}$ & 8 & 33.4375 & 1.297181 & 31.9 & 35.1 \\
\hline \multicolumn{6}{|c|}{ Group 2 (subperiosteal undermining) } \\
\hline $\mathrm{LJ}$ & 8 & 2.625 & .4559136 & 2.1 & 3.4 \\
\hline N-NS & 8 & 8.0625 & .7854709 & 7.1 & 9.1 \\
\hline $\mathrm{AB}$ & 8 & 30.475 & 1.665405 & 27.9 & 32.2 \\
\hline $\mathrm{AC}$ & 8 & 35.6 & 1.847779 & 31.5 & 37.5 \\
\hline $\mathrm{AE}$ & 8 & 58.85 & 2.977055 & 53.4 & 62.1 \\
\hline $\mathrm{HC}$ & 8 & 32.8125 & 1.985978 & 29.4 & 35.5 \\
\hline $\mathrm{BH}$ & 8 & 33.425 & 1.066034 & 31.6 & 34.9 \\
\hline \multicolumn{6}{|c|}{ Group 3 (supraperiosteal undermining) } \\
\hline LJ & 8 & 3.1 & .4956958 & 2.6 & 3.9 \\
\hline $\mathrm{N}-\mathrm{NS}$ & 8 & 7.6875 & .4015593 & 7.3 & 8.4 \\
\hline $\mathrm{AB}$ & 8 & 29.0625 & 1.030863 & 26.8 & 30.0 \\
\hline $\mathrm{AC}$ & 8 & 34.8125 & 1.469147 & 31.9 & 36.5 \\
\hline $\mathrm{AE}$ & 8 & 57.7375 & 1.466714 & 55.5 & 59.7 \\
\hline $\mathrm{HC}$ & 8 & 31.4375 & 1.42522 & 29.0 & 33.9 \\
\hline $\mathrm{BH}$ & 8 & 32.4125 & 1.161818 & 30.6 & 34.3 \\
\hline
\end{tabular}

\section{RESUltS}

Table 1 shows the mean values and SD of the measurements for group 1 (control), group 2 (left side subperiosteal undermining), and group 3 (left side supraperiosteal undermining). For all three measurement dimensions (maxillary length, width, and height), no significant group differences were noted for any measured variables. That is, no differences were observed between the two treatments or between the treated and control animals for any measured variable.

\section{Discussion}

Growth of the maxilla affected by unilateral complete cleft but not treated surgically is almost normal (Ortiz-Monasterio et al., 1966; Mars and Houston, 1990). Many early authors (Graber, 1949; Herfert, 1958; Schweckendiek, 1973) believed that growth impairment of operated cleft lip and palate was due to palatoplasty, and particularly because of lifting and transposing mucoperiosteal flaps. Subsequently, lip surgery has been investigated for its possible detrimental effect on maxillary growth because of supraperiosteal or subperiosteal underminings. Some researchers (Eisbach et al., 1978; Bardach et al., 1982; Bardach and Mooney, 1984; Bardach and Kelly, $1988,1994)$ demonstrated interference of maxillary growth as a result of lip surgery, and these impressions have been confirmed by clinical studies (Normando et al., 1992; Kapuku et al., 1996).

Wide undermining of soft tissues is fundamental to obtain a tension-free repair of the cleft lip. This may be accomplished subperiosteally (Veau, 1938; Skoog, 1974; Delaire, 1975; Trott and Mohan, 1993) or supraperiosteally (Burian, 1968; Millard, 
1976; Bardach and Salyer, 1987). The supraperiosteal approach was meant to avoid negative consequences on maxillary growth.

No experimental studies have been reported comparing these two methods of undermining. In fact, experimental works of Bardach (Bardach and Eisbach, 1977; Bardach et al., 1982; Bardach and Mooney, 1984; Bardach and Kelly, 1988, 1994) considered cheiloplasty after supraperiosteal undermining, and Munro (1978) regarded maxillary growth after subperiosteal undermining of the normal facial skeleton. Our measurements and their analysis show that neither treatment led to any statistically significant differences in maxillary dimensions in comparison with the control group.

It can be concluded that subperiosteal or supraperiosteal undermining does not interfere with maxillary growth on healthy rabbits. However, extrapolation from the rabbit to the human must be made with caution. For example, subperiosteal dissection and reconstruction according to Delaire et al. (1989) involves transposition of periosteum as a tent over the depressed anterior surface of the maxilla. This represents a condition totally different from our experimental model (elevation and reposition in the same place of the periosteum).

\section{ConClusions}

Given that our Cleft Palate Centre has been using subperiosteal undermining in cheiloplasty followed in a second stage by gingivoalveoloplasty and hard palate repair (Brusati and Garattini, 2000) for some years with very good results, we decided to verify whether there was any difference manifest as growth disturbances when conducting subperiosteal versus supraperiosteal undermining.

On the basis of these results, it can be said that neither method interferes with maxillary growth in a statistically significant manner. The aim of our study was to stimulate research toward a specific analysis of the impact of a surgical procedure on the growth of the normal facial skeleton. Further clinical and experimental studies are certainly required to transpose the results of our findings to the therapy of clefts. We must remember that facial growth in children with a cleft lip and palate is inevitably different from that in healthy children (Shaw and Asher-McDate, 1992) and that reposition of the periosteum in the same place is different from transposition of periosteum associated with cleft surgery. A procedure that has no negative effects on a healthy maxilla may still be harmful when used to treat a cleft maxilla.

\section{REFERENCES}

Bardach J, Eisbach KJ. The influence of primary unilateral cleft lip repair on facial growth: 1. Lip pressure. Cleft Palate J. 1977;14:88-92.

Bardach J, Mooney MP. The relationship between lip pressure following lip repair and craniofacial growth: an experimental study in beagles. Plast Reconstr Surg. 1984;73:554-558.

Bardach J, Mooney M, Giedrojc-Juraha ZL. A comparative study of facial growth following cleft lip repair with or without soft tissue undermining: an experimental study in rabbits. Plast Reconstr Surg. 1982;69:745-752.

Bardach J, Kelly KM. Simultaneous cleft lip and palate repair: an experimental study in beagles. Plast Reconstr Surg. 1988;82:31-36.

Bardach J, Kelly KM. The effect of lip repair with or without soft tissue undermining and delayed palate repair on maxillary growth: an experimental study in beagles. Plast Reconstr Surg. 1994;93:267-272.

Bardach J, Salyer K. Unilateral cleft lip repair. In: Bardach J, ed. Surgical Techniques in Cleft Lip and Palate. Chicago: Year Book Medical Publishers; 1987;18-23.

Brusati R, Garattini G. The early secondary gingivoperiosteoplasty. In: Precious DS, ed. Cleft Lip and Palate. A Physiological Approach. Oral and MaxilloFacial Surgery Clinics of North America. 2000;443-453.

Burian F. The Plastic Surgery Atlas. Vol. 2. New York: McMillan; 1968.

Delaire J. La cheio-rhino-plastie primaire pour fente labio-maxillaire congenitale unilaterale. Essai de schematisation d'une technique. Rev Stomatol. 1975;76:193-215.

Delaire J, Precious D, Gordeeff A. Interet des grands decollements sous-periostes dans la correction chirurgicale primaire des fentes labio maxillaires. In: Il trattamento chirurgico e ortodontico della labio-palatoschisi. La ricostruzione dell'equilibrio funzionale. Lipopo, Italy: ALPS; 1989;27-30.

Engdahl E. Bone regeneration in maxillary defects. Scand J Plast Reconstr Surg. 1972;8(suppl):1-8.

Eisbach KJ, Bardach J, Klausner EC. Influence of primary unilateral cleft repair on facial growth: II. Direct cephalometry of the skull. Cleft Palate J. 1978; 15:109-115.

Graber TM. Craniofacial morphology in cleft palate and cleft lip deformities. Surg Gynecol Obstet. 1949;88:359-363.

Herfert O. Fundamental investigations into problems related to cleft palate surgery. Br J Plast. 1958;11:97-102.

Kapuku MR, Gursu KG, Enacar A, Aras S. The effect of cleft lip repair on maxillary morphology in patients with unilateral complete cleft lip and palate. Plast Reconstr Surg. 1996;97:1371-1375.

Mars M, Houston WJB. A preliminary study of facial growth and morphology in unoperated male unilateral cleft lip and palate subjects over 13 years of age. Cleft Palate J. 1990;27:7-13.

Millard DR. Jr. Cleft Craft: The Evolution of Its Surgery. Vol. I: The Unilateral Deformity. Boston: Little Brown; 1976.

Munro JR. The effect of total maxillary advancement on facial growth. Plast Reconstr Surg. 1978;62:751-755.

Normando ADC, Dilva Filho OG, Capelozza Filho E. Influence of surgery on maxillary growth in cleft lip and/or palate patients. J Craniomaxillofac Surg. 1992;20:111-117.

Ortiz-Monasterio F, Serrano-Rebeil AR, Barrera GP, Rodriguez-Hoffman H, Vinageras EA. Study of untreated adult cleft palate patients. Plast Reconstr Surg. 1966;38:36-42.

Schweckendiek W. Die zweizeitidelge gaumenplastik, vorzuge-mengel ergebnisse. Fortschr Kiefer-Gesichtschir. 1973;16:140-146.

Shaw WC, Asher-McDate C. A six-center international study of treatment outcome in patients with cleft of the lip and palate: part 1. Principles and study design. Cleft Palate Craniofac J. 1992;29:393-398.

Skoog T. Plastic Surgery. Philadelphia: W.B. Saunders; 1974.

STATA 6.0. 1984-1999. East College Station, Texas: Stata Corp. http:// www.stata.com.

Trott JA, Mohan N. A preliminary report on one stage open tip rhinoplasty at the time of lip repair in bilateral cleft lip and palate: the Alor Setar experience. Br J Plast Surg. 1993;46:215-222.

Veau V. Bec de lièvre. Paris: Masson; 1938. 